\title{
An Analysis of Errors by Chinese-speaking Korean Learners* Centered on the Errors Produced under the Influence of First Language
}

\author{
Cheng Bing \\ Shandong Women's University, Shandong, jinan
}

\begin{abstract}
A learner's mother tongue, target language, and educational background all contribute to the occurrence of errors. Lingual errors can be classified into: substitution, addition, and omission according to manifestation; and into pronunciation, grammar and vocabulary in accordance with scope. This thesis is focused on the analysis of the errors produced under the influence of first Language by Korean learners in Chinese context. The writer of this thesis makes a documentary research on the collected materials from such linguistic perspectives as pronunciation, grammar, vocabulary etc.. This research project isn't just to stay in the phase of recording errors, but proceeds further to dissect error phenomena one by one by analyzing the reasons causing each of them. Solutions are also proposed with the hope of providing practical learning materials and effective learning methods to Korean learners in Chinese context.
\end{abstract}

KEYWORD: errors; positive transfer; negative transfer; mother tongue; target language

\section{SIGNIFICANCE OF THIS RESEARCH}

It is natural and inevitable for language learners to make mistakes in the process of learning a second language. Error analysis refers to recording and analyzing the errors that appear in the acquisition of a second language. Since 1960, error analysis has always been one of the highly proactive methodologies adopted in the field of foreign language education (FLE) research. In recent years, a good many of achievements on error analysis have been attained in the field of Korean teaching. The purpose of error analysis is to better conduct and improve teaching and learning of a second language by the way of studying the classification, process and causes of errors. The analysis on the lingual errors made by Korean learners in Chinese context will not only provide to learners with diagnosis and assessment of their actual Korean proficiency, but also assist us in exploring more efficient teaching methods of Korean language. For teachers and learners, error analysis can produce more direct, practical and helpful research materials.

\section{METHODS AND SUBJECTS OF THIS RESEARCH.}

This thesis is focused on the analysis of the errors produced under the influence of first Language by Korean learners in Chinese context. The theory relied upon is as follows: what kind of errors occur as a result of effect from mother tongue; which reasons account for such errors; and how they can be overcome. This research not only provides useful information as well as highly effective learning methods for Korean learners in Chinese context but also form the basis for the comparative analysis between Korean and Chinese languages.

In order to identify the causes of errors, and propose effective teaching programs, the first to be done is decide and classify errors. Li Zheng $\mathrm{Xi}$ (2002) proposes that a concrete and substantial error analysis is composed of 5 steps:

(1) Input all the collected materials

(2) Distinguish between correct sentences and erroneous sentences

(3) Modify the erroneous sentences into proper sentences

(4) Classify the errors respectively into categories of pronunciation, grammar, vocabulary and others, and then count the frequency of occurrence separately.

\footnotetext{
* The present essay relates to the research results on the Youth Research Project "An Analysis of Errors by Chinese-speaking Korean LearnersCentered on the Errors Produced under the Influence of First Language" funded by Shandong Women's University.
} 
(5) Conduct a classification analysis of errors based on their categories

The subjects of this research are sophomores majored in Practical Korean, who are studying in School of Foreign Languages of Shandong Women's University. 24 students who have been studying Korean for 1.5 years participated the experiment, of whom 5 have passed TOPIK Band Four and 8 TOPIK Band Three.

\section{MANIFESTATIONS OF ERRORS}

\subsection{Vocal Errors}

\subsubsection{Confusion of the articulation of " - " with " $e$ " and "er" sounds in Chinese Pinyin}

No articulation identical with this Korean sound "-" exists in Chinese. The proximal articulation in Chinese Pinyin is "e". Besides, learners with Chinese context are apt to fall into the influence of retroflex suffixation, so they usually articulate "-" as "er". As a result, "즐" is articulated to be "절", and "바쁘다" to be "바뻐다".

\subsubsection{Confusion of the articulation of " $f$ " with " $e$ " sound in Chinese Pinyin}

When articulating " $f$ ", the mouth opens naturally, with tongue in the middle. Then the tip of the tongue falls downward while the tongue retracts. The back of the tongue rises naturally, making the mouth halfopen naturally. Points of articulation of this alphabet resemble those of "e" in Chinese Pinyin. Consequently, many students directly replace it with "e". In fact, when articulating " $f$ ", the blade of tongue flattens itself naturally, and exerts no force. However, when articulating "e", the back of tongue retracts and does exert force. Due to the lack of homologous sound in Chinese, teaching of " $f$ " can be done in this way: allowing students to experience the places of tongue and the tension of the vocal organs when articulating the vowels in Chinese Pinyin of "bo" and "po". The influence of "e" sound will diminish gradually in this way.

\subsection{3 "上" and "ou"}

As for " $\perp$ ", its manner of articulation has been mentioned in the foregoing paragraph. When making this articulation, vocal organs do not move from beginning to end. By comparison, when articulating the diphthong of "ou" in Chinese Pinyin, the shape of mouth changes when switching from "o" to " $\mathrm{u}$ ". The articulation of " $\perp$ " requires the movement of vocal organs to resemble the way of articulating "o" of "ou".

\subsection{4 "ᄅ", a most frequently erroneously pronounced sound}

When pronouncing this consonant, first approximate the tip of tongue to the upper gum. Then, flip the tip of the tongue lightly while forcing the breath through the mouth. Since there is no flap in Chinese Pinyin, this sound is often pronounced "r", a postapical voiced fricative in Chinese Pinyin, or "l", a mid-apical voiced lateral in Chinese Pinyin, by beginners.

Influenced by Chinese "1", many Chinese learners of Korean tend to apply its manner of articulation indiscriminately when pronouncing "ᄅ". Although the places for articulation of the two sounds are the same, their manners of articulation differ: in the case of "l", the tongue is tightly positioned against the upper gum and the tip of the tongue neither vibrates nor twists. Compared to " $r$ " in Chinese phonetics, the tip of the tongue is closer to the front and it is not twisted as well. In contrast, when articulating "ᄅ", the tip of tongue must be lightly flipped when the breath passes it.

At the moment of finishing articulating "ㄹ", it is very likely to be mispronounced as a Chinese retroflex suffix. Thus, "말" is pronounced as [mar], due to the fact that its learners are unable to flip the tip of tongue naturally and unconsciously concentrate the strength at the back of tongue.

\subsection{Lexical Errors}

Chinese and Korean belong to different language families but they are still closely related. Many Korean words derive from ancient Chinese. Korean lexical system contains Sino-Korean words, pure Korean words and foreign words. Sino-Korean words beat a path into the Korean language system along with the importation of Han culture into Korean, most of which are used to express abstract or logistic meanings. Sino-Korean words and Chinese characters sound alike, but the pronunciation of the former is unique in a way: namely, the original Chinese pronunciation is altered by Korean pronunciation rules and mechanisms. For quite a long time in history, Chinese characters were held in high esteem and used in formal, honorable occasions. The abundance of Sino-Korean words makes the acquisition of Korean vocabulary unavoidably unique. Language transfer occurs in the process of Korean acquisition by Chinese students.

\subsubsection{Chinese-style Vocabulary}

The theory of language transfer believes that language learners are mainly disturbed by existing languages; old language habits impede the formation of new ones; and the former must be rectified in order to facilitate the formation of the latter in learning a new language. Therefore, when speaking 
of the relationship between mother tongue and target language, what first comes to mind is the interference effect of mother tongue in the process of learning a foreign language. Chinese-style words are such errors made by learners whose mother tongue is Chinese in their learning of Korean. They use Chinese words directly in Korean language.

Errors of this type are shown as follows:

(1) 서로 사상이 (생각이 $\sqrt{ }$ ) 다르다

(2) 부모님이 생일에 신 (새 $\mathfrak{V})$ 운동화를 사주었다

(3) 착하고 관용한(너그러운 $\sqrt{\text { ) }}$ 마음을 구비한다(가진다 $\boldsymbol{S}$.

Chinese-speaking learners tend to metaphrase Sino-Korean words into pure Korean words. Particularly, when encountering unknown or unfamiliar pure Korean words, they are apt to mechanically write out Sino-Korean words pursuant to Korean pronunciations.

\subsubsection{Collocational errors and those with passive and causative words}

In the grammatical and connotational sense, lexical errors take the form of collocational errors and those with passive and causative words. For example, the Chinese will say "打电话(make a call), 踢足球(play football), 打扫卫生(do some cleaning)", in which the nouns play a qualifying role on the preceding verbs, making collocations of this type possess certain stability. If a learner's command of vocabulary were not good enough, he would have made a lot of errors in this regard.

Examples of Collocational Errors

(1) 동생의 키는 적다(작다 $\boldsymbol{J}$ ).

(2) 친구의 나이가 좀 크다 (많다 $\sqrt{ }$ ).

The above examples fall under the influence of Chinese language, having collocational errors made by using Chinese-style expressions in a direct way.

\subsection{Grammatical Errors}

\subsubsection{Errors with Word Order}

In accordance with the classification of linguists, linguistic elements are divided into Subject (S), Predicate (V) and Object (O), forming six types of word order in theory. One of the main Korean features is SOV order, the predicate placed after the subject and the object, making Korean an Agglutinative Language. This is in sharp contrast to SVO-order Chinese. Chinese is an Isolating Language, the predicate placed after the subject but before the object. For example:

(1)내가 밥을 먹는다. (I-a meal-have)

(2)내가 그녀를 좋아한다. (I-her-like)

This type of syntactic structure is fundamentally different from that of Chinese. In Chinese, these two sentences should be "我吃饭(I have a meal)" and "
我喜欢她(I like her)" respectively. Hence, Chinese students who are used to expressing grammatical relations in the way of SVO order are apt to make such mistakes at the early stage of learning Korean, but as the learning deepens, they will consciously take the initiative to change their intrinsic lingual mindset of Chinese language and to think and speak with the SOV order existing in Korean. Korean language abounds in case-auxiliary words, further rendering its word orders more elastic.

(1) 밥을 내가 먹는다. (a meal-I-have)

(2) 그녀를 내가 좋아한다. (her-I-like)

Although the positions of both objects and subjects in the previous two sentences are altered, their basic meanings are not impaired. Since grammatical relations in Korean are specially borne by affixes with grammatical meanings, the arrangement of Korean sentence elements is not so rigid.

Regardless of how the sentence elements in Korean are variously arranged, the predicate is surely positioned at the end of a sentence and the syntax must follow the rules of SOV order.Also, Errors caused by misplacement of numerals are also not rare. For example:

(1) 우리 반 세 명 남자(남자 세 명 $\sqrt{ }$ ) 있다.

(Three men)

(2) 한 송이 장마꽃 (장미꽃 한 송이 $\sqrt{ }$ )을 샀다. (A bouquet of roses)

The reason for those errors derives from the influence of Chinese word order, in which the numeral and the quantifier are both placed prior to the noun. By contrast, in Korean the numeral and the quantifier are located after the substantive, so the above examples shall be rewritten as "men three" and "roses a bouquet" separately in Korean-style word order.

\subsubsection{Omission and misuse of auxiliary words}

In Korean, main grammatical relations are reflected by auxiliary word(s) or suffix(es). Normally various auxiliary words are appended after subjects, predicates and objects. Chinese language does not rely on auxiliary words to express grammatical relations, so many Chinese--speaking Korean learners are likely to omit auxiliary word(s) on account of mother tongue interference. For example:

(1) 나 대학생이다.

(2) 저 김치 좋아합니다.

The complementary auxiliary "는" and the purpose case-auxiliary "를" are omitted separately in the above two sentences. Although these sentences are narrowly able to express their meanings, they do not meet the rules of Korean grammar. This has always been an entrenched problem of Chinese students studying Korean. A concrete analysis of several auxiliary words is made below, because these words are more frequently misused by students. 
(1) Misuse between "이/가" and "은/는"

Nominative auxiliary words do not exist in Chinese language, so Chinese-speaking Korean learners often confuse "이/가" with "은/는". For example:

(1) 버스는 $($ 가 $\mathfrak{l})$ 출발했다.

(2) 한국이 처음이 (은 $\sqrt{ }$ ) 아니다.

(3) 네가(나는 $\sqrt{ })$ 한국말을 배우고 철수씨가(는 $\sqrt{ })$ 영어를 배운다.

"이/가" is used after a substantive to enable it to serve as the subject. In casual conversations, "이/가" shall be applied when the subject of a sentence is third-person and referred to for the first time, or when answering a question with an interrogative like "누구, 무엇, or 어디" as its subject. "은/는" indicates the subject of a sentence, and also states the subject of narration when affixed after a substantive. As a complementary auxiliary, "은/는" implicates emphasis and comparison. What differentiates it from "이/가" is that "은/는" applies when a previously-mentioned object is referred to again in a conversation.

(2) Misuse between "에" and "에서"

Either"에" or "에서" is able to indicate a location, both of which can be understood as "在(at/in)" in Chinese. Their usages, however, differ from one another. "에" denotes an existent locale or destination, commonly used together with directional verbs like "come, go, arrive" etc.. "에서" implicates performing a certain action in a locale. For example:

(1) 학교에서(에 $\mathfrak{V})$ 간다.

(2) 교실에(에서 $\sqrt{ })$ 한국어를 공부한다.

Meanwhile, "에" can also be used to signify time, and "에서" site of departure. For example:

한 시에 점심을 먹었습니다.

미국에서 왔습니다.

Anyway, both "에" and "에서" carry a complexity of diverse usages. It is not enough to approach them merely on the basis of mother tongue. Instead, an analysis of the specific semantic meaning of a sentence is necessary.

(3) Misuse of the genitive forma "의"

"의" is placed after a substantive, indicating ownership, equivalent to "的(of)" in Chinese. Let's examine an example with an error of this type.

(1) 한국에 $($ 의 $\mathfrak{V})$ 날씨가 좋다.

As for this sentence, both omitting "에" and changing it into "의" are right. The existence of "한국", a location-indicating noun, at the beginning of the sentence easily misleads students to wrongly choose such an adverbial case particle as "에". Moreover, due to the fact that"의" is pronounced as "에" in Korean, Korean learners are often liable to miswrite "의" with "에". Notwithstanding the correspondence of "의" to the Chinese word "的", the latter is not necessarily required to be translated into "의". For example:
(1) 美丽的花朵 (beautiful flowers)

（2）我的书包 (my schoolbag)

“的”of the first sentence signifies that its preceding adjective is used as an attribute, while that of the second sentence indicates ownership. When translated into Korean, they shall be “예븐 꽃" and "나의 가방" separately. Therefore, a proper analysis of the properties of words guarantees the proper use of genitive forms.

\subsubsection{Misuse of suffixes}

Chinese is an Isolating Language but Korean is an Agglutinative Language. A Korean suffix is a morpheme without lexical meaning, and it can only be attached to verbs or predicative phrases or sentences, embodying various grammatical meanings. Suffixes are numerous in Korean, constituting an obstacle for many Chinese students.

(1) Errors of heading words as suffixes

(1) 나는 맵다 (매운 $\sqrt{ }$ ) 음식을 좋아한다.

(2) 사랑한(사랑하는 $\sqrt{ }$ ) 선생님께

(3) 밥을 먹(먹은 $\sqrt{ }$ ) 후에 텔레비전을 봤다.

"맵다"in the first sentence is an adjective, and it is wrongly modeled after Chinese grammar. In Chinese, adjectives can directly serve as attributes, but in Korean, only by transforming an adjective into a heading word can it modify the substantive following it. In the second sentence, despite the actual transformation of the adjective into a heading word, the negligence of tense still exists. The third sentence is obviously affected by Chinese language, because the suffix of heading-word nature is omitted.

\subsubsection{Misuse of Honorific Rules}

Honorific rules are not only a main feature in Korean but always prove to be a key point as well as a difficulty. Korean language contains within itself a highly intact system of honorific rules with two forms of manifestation, lexical and grammatical.

In the grammatical sense, "(으)시" is commonly used to convey respect. The following errors are produced as a result of want of honorific application.

(1)선생님이(께서 $\mathfrak{V}$ ) 갔습니다(가셨습니다 $\sqrt{ }$ ).

(2)저는 할머니에게(할머니께 $\sqrt{ }$ ) 선물을주셨습니다(드렸습니다 $\boldsymbol{V}$ ).

(3)할아버지께서는 나이가 (연세가 $\sqrt{ }$ ) 많습니다(많으십니다 $\overline{\boldsymbol{J}}$ ).

The "teacher" in the first example is the behavioral subject worthy of our reverence, so the auxiliary before it should be a choice bearing a respectful implication. Additionally, the predicate following it shall be added with a respectful ending, that is, "(으)시". The "grandma" in the second example is both the object of the sentence and an object demanding respect, so an auxiliary word bearing a respectful implication is needed after this 
appellation. Caution shall be made that no "(으)시" is appended to the predicate because the subject of this whole sentence is "I", and it is improper to pay homage to oneself. Instead, the verb "give" shall be replaced with "dedicate", a word of respectful implications, to achieve the desired effect. The behavioral subject in the third example is "grandpa", so "연세" shall be used to express respect when referring to his age. Meanwhile, a respectful ending shall be added after "grandpa".

\section{EFFECTIVE GUIDELINES AIMED AT ERRORS}

\subsection{Strengthening the contrastive analysis between Chinese and Korean and clarifying important and difficult points}

Contrastive analysis is a good way to conduct language teaching and research. At the very beginning, Chinese characters were used by Koreans. As time went by, Korean language roughly went through two phases: using Chinese characters in Chinese manner and subsequently in Korean manner. Korean-specific words were created on the basis of Chinese characters in the long history. And both the connotations and denotations of existing Chinese words underwent certain changes until they completely assume the forms in modern Korean. Consequently, Chinese students would be unavoidably influenced by their native language in learning Korean. So, we have to strengthen and value the contrastive analysis between Chinese and Korean in order to find ways to exploit positive transfer and avoid negative transfer of mother tongue.

\subsection{Enhancing cultural input and fostering cultural cultivation}

Language is the carrier of culture. Thus, in the process of second language acquisition, people will inevitably encounter a lot of cultural phenomena that are unfamiliar to them or difficult to understand. Most of the cultural factors that affect language comprehension and use are hidden in the lexical or grammatical system of a language. Within teaching practices, teachers shall explain to students the national characteristics included in pronunciation and vocabulary.

\subsection{Exposing students to the context and inducing readings}

Reading is able to expose students to the context, which will lead them to understand words in it, and to redress negative transfer of mother tongue. Reading also helps to cultivate the sense of language. The theory of second language acquisition believes that the language of a learner is a dynamic system and continuum between the native language and the target language. The purpose of learning a foreign language is to realize communication with others in this language. Teachers shall selectively instruct students in reading, expose them to the context, and cultivate their language sense in order that they can grasp this language.

\section{CONCLUSION}

This thesis explores the lingual errors produced by Chinese-speaking learners as a result of effect from mother tongue. Within it, lingual errors are sorted and analyzed from three aspects---articulation, grammar and vocabulary. For instance, Chinesespeaking learners are frequently influenced by their native language in learning Korean pronunciation, which eventually leads to their inaccurate mastering of Korean pronunciation. In the lexical aspect, learners tend to confuse pure Korean words with their corresponding Sino-Korean words. In terms of syntax, Chinese is an Isolating Language, majorly depending on the word order to exhibit grammatical relations. Korean is an Agglutinative Language, in which the formation of words and the manifestation of grammatical relations primarily count on the combination between stems and grammatical morphemes like auxiliaries and endings. Because of these differences, Korean learners within Chinese context are liable to make mistakes in declension of substantives and flexible use of predicates. In addition, this thesis makes an attempt to explain the factors that engender lingual errors and simultaneously propose effective solutions to remedy these errors. Despite possible limitations, the author still hopes to produce a piece of useful information guiding Chinese-speaking learners in learning Korean.

\section{REFERENCES}

[1] $\mathrm{Xu} \mathrm{Zi}$ Liang. A Psychological Analysis of Foreign Students' Korean Learning Strategies. Chinese Teaching in the World. 1999

[2] Zhu Ying Yue. A Comparison of Initial Consonants between the Pronunciation of Sino-Korean Words and Mandarin Chinese. Chinese Language Learning. 2000(2)

[3] $\mathrm{Hu}$ Ying. An Analysis on Errors Related to Function Words by Second Language Learners. Language and Translation. 2003(1)

[4] Wu Shan Zi. A Comparative Study of Rhetorical Modal Adverbs between Chinese and Korean. Shanghai International Studies University. 2010

[5] Kwon Hyun Jong. A Contrastive Analysis of Chinese Prepositions and Korean Adverbial Case Particles and Their Teaching Strategies. Shandong University. 2013 